\title{
Neuropsychological sequelae in attention and memory in women victims of gender- based violence and their implication in depression. A Multivariate Analysis
}

\author{
Torres García, A.V ${ }^{1}$.; Vega Hernández, M. C ${ }^{2}$; Antón Rubio, $C^{3}$.; Pérez Fernández, M. ${ }^{1}$ \\ University of Salamanca \\ ${ }^{1}$ Faculty of psychology. Department of personality, psychological evaluation and \\ treatment \\ ${ }^{2}$ Faculty of medicine. Department of statistics \\ ${ }^{3}$ Faculty of psychology. Department of social psychology and anthropology
}

\begin{abstract}
Women victims of abuse can suffer neuropsychological sequelae that affect memory and attention, as well psychopathological disorders such as depression. These consequences affect their daily life and physical and psychological health. Objective: To analyze sequelae that affect attention and memory, as well a possible association of these sequelae to depression. Method: A total of 68 women victims of gender-based violence participated in the study. The participants were between 15 and 62 years of age and resided in Spain at the time of data collection. The Luria DNA Battery (Neuropsychological Diagnosis of Adults) by Manga and Ramos (2000); and the Beck Depression Inventory were applied. Results: Women victims of gender-based violence suffer neuropsychological sequelae, presenting low short-term memory and attentional control; and score low on the Luria-DNA battery. Of these women, $60 \%$ suffer from some relevant type of depression, and there are significant differences according to their degree of memory. Through the HJ-Biplot, a direct relationship was found between memory and attentional control with the total score of the Luria battery. On the other hand, an inverse relationship was found between short-term memory and depression. Lastly, three welldifferentiated gender clusters of women victims of gender-based violence were identified. Conclusions: A lower rate of depression is observed in women victims of abuse when they have a more intact short-term memory.
\end{abstract}

Keywords: abused women, neuropsychological sequelae, attention, memory, depression, Luria DNA battery

\section{Introduction}

Women who are victims of gender-based violence can present neuropsychological sequelae that will affect their life, especially in their day to day (Torres 2014), while also presenting a diversity of physical, psychological, neurological, and cognitive problems (Fonzo, Simmons, Thorp, Norman , Paulus, \& Stein, (2010); Simmons, Paulus, Thorp, Matthews, Norman \& Stein (2008); Valera \& Berenbaum, 2003). This population makes up a particularly vulnerable group that requires not only psychological, but also neuropsychological care (Lozano-Ruiz et al. 2019).

Currently, there is no doubt that this type of violence affects the quality of life and wellbeing of the victims. These consequences may appear immediately, but on other occasions they manifest later on and may become irreversible as a consequence of the cumulative 
effect of violent episodes (Boira, Carbajosa \& Méndez, 2015; Campbell, 2002; Glaiser, Gülmezoglu, Schmid, Moreno, \& Van Look, 2006; Ellsberg, Jansen, Heise, Watts, \& García Moreno, 2008; UN, 2015; Sugg , 2015 cited in Jaén, Rivera, Amorín \& Rivera, 2015).

Research from the field of neuropsychology related to gender-based violence is still scarce, despite the fact that the results of studies indicate that there are important neuropsychological sequelae (Marín Torices, Hidalgo-Ruzzante, Daugherty, JiménezGonzález, \& Pérez García 2018; Torres, 2014; Valera \& Kucyi, 2017). Research makes reference, among other things, to attention and memory problems, and these alterations have been observed in deficiencies in executive functions, memory and processing speed (Seedat, Stein, \& Forde, 2005).

Navarro, León \& Nieto (2020) found worse performance in tasks of alternating attention and in memory, both in short-term, and direct/ indirect visual memory in abused women when compared with non-abused women. These results are in the same line as those found by Twamley et al., (2009)

The areas of memory, attention, and concentration are especially compromised in that women show greater distractibility problems, significant difficulties in concentration and in remembering everyday events, as well as in contained and sustained attention as a consequence of having been exposed to violence. Other areas that affect visuoconstructive ability and executive functions, as well as fluency speed and motor processing are also impacted, affecting decision-making and response inhibition (Browne, 1993; Jackson, Philip, Nuttall \& Diller, 2002; Stein, Kennedy \& Twamley, 2002; Torres \& PérezFernández 2018; Twamley et al., 2009; Valera \& Berenbaum, 2003).

On the other hand, research on gender-based violence and autobiographical memory is still unexplored, despite the fact that the impact of autobiographical memory dysfunction in everyday life has already been demonstrated. Billoux, Arbus, Telmon, \& Voltzenlogel (2016) indicate that there is autobiographical memory dysfunction in women victims of gender-based violence, and follows a pattern similar to this type of memory deterioration in victims of traumatic events. The results of the research carried out by Bunnell \& Greenhoot (2012) on autobiographical memory problems related to depression, posttraumatic stress disorder, working memory and attention biases in abused adolescents indicate the existence of an opposite relationship in terms of the severity of the abuse and a lower specificity of memory. This relationship was explained by coping through lack of commitment and symptoms of Post-Traumatic Stress Disorder, meaning this low specificity in memory can be a form of avoidance, and these avoidance mechanisms depend on the context of the memory.

According to Torres \& Pérez-Fernández (2018), women who have suffered genderbased violence score lower in the execution of the different areas of the Luria DNA neuropsychological battery when compared with a group of non-abused women. This shows that there is a neuropsychological impact in the visuospatial area (visual perception and spatial orientation), language area (receptive speech and expressive speech), memory area (short-term memory and logical thinking), intellectual area (thematic drawings and conceptual activity), and in the attention test (attentional control). These results are in line with other studies that show how women victims of abuse show cognitive problems related to physical and psychological abuse, as well the chronic stress produced by it (Jackson, Philip, Nuttall \& Diller, 2002; Kwako, Glass, Campbell, Melvin, Barr \& Gill, 2011). 
Hidalgo-Ruzante et al. (2012) makes reference to the cognitive sequelae of genderbased violence due direct damage as a result of blows received to the head, as well indirect damage from exposure to violence that causes psychopathologies, such as post-traumatic stress disorder (PTSD), which entails cognitive and psychological sequelae. On the other hand, injuries caused by blows to the head produce problems in attention and executive functioning (Torices, Hidalgo-Ruzante, Sabio \& García, 2016). Other studies in this line show that violence is related to a greater neuropsychological deficit and important psychopathological symptoms. Poor results in working memory would be related to high levels of stress, and there are significant differences that relate abuse to impairment in longterm and visual working memory, although no significant differences were found regarding psychopathological symptoms, such as anxiety, depression and stress; and cognitive deficits (Navarro, León \& Nieto, 2020).

On the other hand, experiencing victimization may negatively affect women's emotional stability. In addition to physical injuries caused by violence, they may present depression, anxiety, post-traumatic stress disorder, suicidal ideation, somatizations, low self-esteem, disability and death (Delara, 2016; Echeburúa \& de Corral, 2015); and behavioral problems related to substance use and suicide attempts (Delara 2016).

Navarro, León \& Nieto (2020) consider that this may be due to the fact that most of the studies analyze independently, instead of jointly, the relationship between psychological abuse and psychopathological symptoms along the relationship between physical abuse and cognitive deficits. In our research we will analyze the association of neuropsychological sequels related to memory, attention and depression.

\section{Materials and Methods}

\section{Participants}

A total of 68 women victims of gender-based violence participated in the study. Out of the sample, $40.63 \%$ suffered abuse for more than 10 years, $18.75 \%$ for less than 3 years, and $40.63 \%$ between 4 and 10 years. The participants age ranged between 15 and 62 years, and lived in Spain at the time of the data collection.

\section{Procedure}

In order to obtain the sample, due to the peculiarities and access difficulties (especially for protection reasons), a collaboration of public and private organizations that work with this population was required (Law enforcement forces: Civil Guard, Corps National Police Corps, Local Police and Autonomous Police; Social Action Centers (CEAS in Spanish), associations and shelters for women victims of violence, hospitals and universities, among others). The study was presented by the research team to the different institutions involved. First, a personal interview was arranged with the head of each institution in order to inform them of the characteristics of the research, as well provide them with brochures and information cards that could facilitate contact with women victims of violence who could be referred to participate in the study. As such, the selection of the participants was carried out through consecutive sampling, selecting women who met the inclusion criteria specified in the protocol as they were recruited. 


\section{Ethical aspects}

The participants signed a consent document at the time of conducting the interviews. This protocol was approved by the research ethics committee of the Institute of Women and the Ministry of Labor and Social Affairs.

\section{Instruments}

\section{Luria DNA battery (Neuropsychological Diagnostic of Adults)}

The Luria DNA battery (Manga \& Ramos, 2000) is a neuropsychological assessment and diagnosis instrument for adults based on the model created by Luria. This battery completes neuropsychological evaluations in all evolutionary stages, as it can be applied to subjects between 16 and 65 years of age. The Luria-DNA battery meets the criteria of thoroughness and time required in all neuropsychological batteries, according to Kolb \& Whishaw (1986), and is defined as comprehensive and selective at the same time (Manga $\&$ Ramos 2000). It is comprehensive because it encompasses all the five areas of cognitive functioning that are considered dominant in the exploration of a possible deterioration from the perspective of clinical and selective practice. This means it allows the exploration of higher psychological processes (visuospatial area, language, memory, intellectual processes and attention), in a short period of time (approximately 40 minutes of test when performed by trained professionals). The battery contains 81 items, distributed in eight subtests.

Among the areas explored by this instrument are memory, one of the most important fields of neuropsychological exploration, with two subtests that evaluate two different types of memory: Short-term memory and Logical thinking.

Short-term memory: Evaluates a type of memory linked to the perception process and includes the consolidation of impressions of the subject. It explores the learning process through five trials of a series of unrelated words that must be remembered in any order. Additionally, it explores retention and evocation in verbal and non-verbal tasks. Verbal memory is examined in a broader way using words, numbers and phrases, sometimes with the presence of interferences. This exploration is completed with the presentation of a story in which the subject has to indicate its essential semantic components, which serves at the same time as an interference of certain verbal orders.

Logical thinking: Evaluates a type of memory linked to complex intellectual processes. The deficit in the use of active auxiliary aids at the service of mnesic and intellectual processes is associated with frontal lobe dysfunctions. Indirect memorization is explored through relationship processes that are established between words and cards, or between expressions and drawings made by the subject itself. The deficit in the use of active auxiliary resources that are at the service of mnesic processes in intellect is associated with dysfunctions in the frontal lobes.

In addition, attention plays a fundamental role in cognitive functioning, thus, it is another of the key areas that the Luria DNA battery evaluates.

Attentional control: Aims to find out the capacity for attention control or functioning. Attention-concentration is analyzed using opposite verbal and non-verbal responses, where the subject has to select responses that conflict with common ones, requiring the inhibition of easier and automated responses. Response association, their omission, or sounds that are difficult to discriminate from each other are also explored. Lastly, sustained attention is 
explored in following words that do not contain a specific vowel sound. With these items, the momentary state of the selective and sustained attention capacity of the evaluated subject is tested.

\section{Beck Depression Inventory}

The Beck Depression Inventory (Beck, Ward, Mendelson, Mock \& Erbaugh, 1961; Beck, Rush, Shaw \& Emery, 1979) is one of the most widely used self-report instruments to assess depressive symptoms in adolescents and adults.

\section{Data analysis}

A descriptive analysis of the variables related to the neuropsychological diagnosis and depression was carried out to assess cognitive functioning and possible sequelae in women victims of gender-based violence. To categorize the women, according to the scores of the Luria-DNA battery, the quartiles of the total scores of each variable were calculated in order to construct four intervals (very low, low, high and very high) based on the amplitude of responses obtained (see Table 1). Classifying $25 \%$ of the women with the highest scores in the "very high" group, the next 25\% as "high", the following 25\% with "low", and $25 \%$ of the women with the lowest scores in "very low". In the case of depression, the instructions of the Beck depression inventory's authors were followed.

Table 1. Descriptive statistics of the neuropsychological diagnostic variables (LuriaDNA battery) to build classification intervals.

\begin{tabular}{lccccc}
\hline & Minimum & Maximum & $\mathbf{Q}_{\mathbf{1}}$ & $\mathbf{Q}_{\mathbf{2}}$ & $\mathbf{Q}_{\mathbf{3}}$ \\
\hline Short-term memory & 10 & 70 & 31.25 & 40.00 & 55.00 \\
Logical thinking & 0 & 70 & 21.25 & 40.00 & 55.00 \\
Attentional control & 0 & 60 & 30.00 & 45.00 & 55.00 \\
Total score Luria-DNA & 0 & 75 & 25.00 & 40.00 & 55.00 \\
\hline
\end{tabular}

Note: $\mathrm{Q}=$ Quartile

An analysis of variance (ANOVA) was carried out with the depression variable among the groups of women victims of gender-based violence in accordance to the degree of their neuropsychological evaluation (very low, low, high and very high) since the data met the assumptions of normality and homoscedasticity, except in the attentional control, in which case the Kruskal-Wallis test was used instead. In case of finding significant differences between the groups of women, post hoc analyzes with Bonferroni adjustment were carried out to find out between which groups these differences occurred.

To analyze possible relationships between the variables under study, a bivariate correlation analysis was carried out and, in order to study the relationship between the results obtained in the neuropsychological evaluation and the results obtained in the depression variable in abused women, a regression analysis was performed afterwards. The latter consisted of two analysis: a model with the total score of the Luria-DNA battery as the explanatory variable, and a second model taking into account the neuropsychological variables (Short-term memory, Logical thinking, and Attentional control). Furthermore, in order to analyze in greater depth the relationships between the variables in abused women victims, a multivariate analysis was performed using HJBiplot (Galindo, 1986). This biplot method allows women, depression, and 
neuropsychological variables to be represented in a single graph of the highest quality of representation, which means that their relationships can be interpreted visually. It is based on the singular value decomposition of the Xnxp matrix: $\mathbf{X}=\mathbf{U} \mathbf{D} \mathbf{V}^{\prime}$ where $\mathbf{J}=\mathbf{U} \mathbf{D}$ and $\mathbf{H}=\mathbf{D} \mathbf{V}^{\prime}$. For the interpretation it must be taken into account that the variables are represented as vectors and the individuals (women in this case) as points in the graph, the distance between the points indicates dissimilarity between women victims of genderbased violence, the length of a vector expresses variability of the variable, the cosine of the angle between vectors indicates correlation between variables, and the projection of a point on a vector indicates the relationship between the woman and the variable.

Lastly, the biplot coordinates were analyzed using a hierarchical cluster analysis.

The data were analyzed using IBM SPSS Statistics package, Version 26.0 (IBM Corp, 2019) and the biplotbootGUI R package (Nieto et al., 2019).

\section{Results}

Neuropsychological sequel in memory and attention in women victims of gender violence

The results of the Luria-DNA battery in women victims of gender-based violence indicate, paradoxically, that short-term memory has the highest score $(\mathrm{M}=41.32, \mathrm{SD}=$ $14.978)$, followed by attentional control $(\mathrm{M}=40.74, \mathrm{SD}=18.310)$ and the total score of the battery $(\mathrm{M}=38.13, \mathrm{SD}=18.066)$, while, as expected, the lowest score corresponds to logical thinking $(\mathrm{M}=37.21, \mathrm{SD}=19.440)$.

Table 2 shows the classification of women based on the range of responses from the Luria-DNA battery. We observe that the highest percentages in women victims of genderbased violence are those with low short-term memory (30.88\%), very low and high logical thinking (29.31\% in both cases), low attentional control $(29.41 \%)$, and a low total score in the battery $(31.34 \%)$.

Table 2. Distribution of women victims of gender-based violence, according to the range of responses of the Luria-DNA battery

\begin{tabular}{lcccccccc}
\hline & \multicolumn{2}{c}{$\begin{array}{c}\text { Short-term } \\
\text { memory }\end{array}$} & \multicolumn{2}{c}{$\begin{array}{c}\text { Logical } \\
\text { thinking }\end{array}$} & \multicolumn{2}{c}{$\begin{array}{c}\text { Attentional } \\
\text { control }\end{array}$} & \multicolumn{2}{c}{$\begin{array}{c}\text { Total score } \\
\text { Luria-DNA }\end{array}$} \\
\cline { 2 - 10 } & $\mathrm{n}$ & $\%$ & $\mathrm{n}$ & $\%$ & $\mathrm{n}$ & $\%$ & $\mathrm{n}$ & $\%$ \\
\hline Verylow & 17 & 25.00 & 17 & 29.31 & 18 & 26.47 & 20 & 29.85 \\
Low & 21 & 30.88 & 12 & 20.69 & 20 & 29.41 & 21 & 31.34 \\
High & 18 & 26.47 & 17 & 29.31 & 16 & 23.53 & 15 & 22.39 \\
Veryhigh & 12 & 17.65 & 12 & 20.69 & 14 & 20.59 & 11 & 16.42 \\
\hline
\end{tabular}

Depression in women victims of gender violence

The mean score in the Beck depression inventory for women who have experienced gender-based violence is 18.36 , with a standard deviation of $11.946 .59 .02 \%$ of women victims of gender-based violence were classified with some relevant type of depression: $14.75 \%$ with mild depression, $24.59 \%$ with moderate depression, and $19.67 \%$ with severe 
depression; while $40.98 \%$ of the women were classified with minimal depression (see Figure 1).

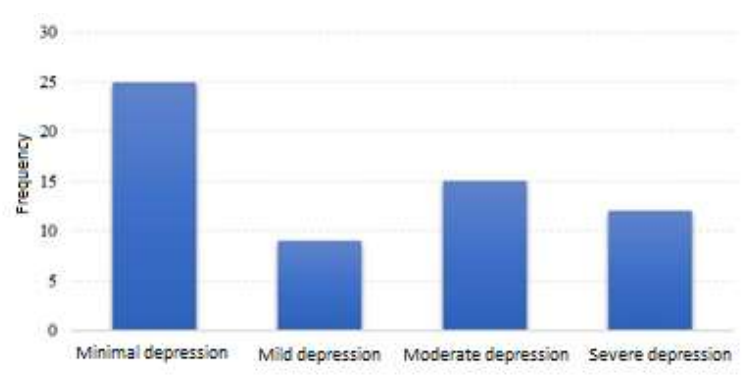

Figure 1. Distribution of women victims of gender violence according to the degree of depression.

Significant differences were found in the depression score between the groups of women victims of gender violence, according to the degree of short-term memory $(\mathrm{F}=4.129$, $\mathrm{df}$ $=3, p=0.010)$ and according to the total score of the Luria-DNA battery $(\mathrm{F}=3.356, \mathrm{df}$ $=3, p=0.025)$. On the other hand, no differences were found in these groups of women according to long-term memory $(\mathrm{F}=1.172, \mathrm{df}=3, p=0.330)$ or attentional control (Kruskal-Wallis $=0.762, \mathrm{df}=3, p=0.858)$.

Post hoc tests show differences in depression between women with very low short-term memory and those with a high and very high level ( $p<0.05$ in both cases), as well between women with high and very high short-term memory $(p<0.05)$. It was also found that the groups with lower levels of short-term memory present higher scores in depression and, as the groups show higher levels of short-term memory, depression scores decrease.

The differences observed in terms of depression between the groups of women victims of gender-based violence, according to the total score of the Luria-DNA battery, are found between women who show very low scores in the neuropsychological diagnostic battery and those who present high scores $(p<0.05)$. The former show high depression scores, while the latter low depression scores.

\section{Association between neuropsychological sequelae and depression}

Table 3 presents the Pearson correlation coefficients between short-term memory and logical thinking scores, as well as the total Luria-DNA score and the Beck depression inventory. We observe direct and highly significant linear relationships between the scores of short-term memory, logical thinking, attentional control and the Luria-DNA total score, on the other hand, these neuropsychological variables appear inversely related to Beck's total depression score. Significant correlations were found with logical thinking and the total score of the Luria-DNA battery ( $p=0.024$ and $p=0.010$, respectively), but above all, a highly significant relationship with short-term memory $(p<0.01)$. This indicates that as scores on the memory variables or the Luria-DNA battery increase, scores on the depression inventory decrease. Furthermore, we did not observe significant relationships between depression and attentional control. 
Table 3. Correlations between neuropsychological and depressive variables studied

\begin{tabular}{lccccc}
\hline & $\begin{array}{c}\text { Short-term } \\
\text { memory }\end{array}$ & $\begin{array}{c}\text { Logical } \\
\text { thinking }\end{array}$ & $\begin{array}{c}\text { Attentional } \\
\text { control }\end{array}$ & $\begin{array}{c}\text { Total score } \\
\text { Luria-DNA }\end{array}$ & $\begin{array}{c}\text { Beck } \\
\text { depression }\end{array}$ \\
\hline $\begin{array}{l}\text { Short-term } \\
\text { memory }\end{array}$ & 1 & $0.517^{* *}$ & $0.448^{* *}$ & $0.816^{* *}$ & $-0.445^{* *}$ \\
$\begin{array}{l}\text { Logical } \\
\text { thinking }\end{array}$ & & 1 & $0.355^{* *}$ & $0.708^{* *}$ & $-0.289^{*}$ \\
$\begin{array}{l}\text { Attentional } \\
\text { control }\end{array}$ & & 1 & $0.640^{* *}$ & -0.148 \\
$\begin{array}{l}\text { Total score } \\
\text { Luria-DNA }\end{array}$ & & & & $-0.328^{*}$ \\
$\begin{array}{l}\text { Beck } \\
\text { depression }\end{array}$ & & & & 1 & 1 \\
\hline
\end{tabular}

Note: $* * \mathrm{p}<0.01 * \mathrm{p}<0.05$.

We explored the effects of neuropsychological evaluation on the depression of women victims of gender-based violence. To this end, we carried out several regression analyzes in which the Beck depression inventory score variable was regressed to the total score of the Luria-DNA battery, and subsequently to the neuropsychological variables (Short-term memory, Logical thinking and Attentional control).

The results of the first model show that the total score of the neuropsychological evaluation could explain $10.8 \%$ of the variance of depression in women victims of abuse. The estimated value of $\beta_{1}$ indicates that the value of the score in depression decreases by -0.211 for each point increase in total score of the Luria-DNA battery. However, the results of the second model show an increase of $10.1 \%$ in the variance of depression. These results show that women who have suffered gender-based violence and score high in short-term memory have lower depression values. The variables of logical thinking and attentional control were not significant, and only the short-term memory coefficient was found significant $(\mathrm{p}<0.01)$ for model fit. 
Table 4. Regression analysis for neuropsychological variables predictive of depression.

\begin{tabular}{|c|c|c|c|c|c|c|c|c|c|}
\hline Modelo & & B & $\mathbf{S E}_{B}$ & Beta & $\mathbf{t}$ & $p$ & $\mathbf{R}^{2}$ & $\mathbf{F}$ & $p$ \\
\hline \multirow[t]{2}{*}{1} & (Constant) & 26.228 & 3.399 & & 7.717 & 0.000 & 0.108 & 7.013 & 0.010 \\
\hline & $\begin{array}{l}\text { Total score } \\
\text { Luria-DNA }\end{array}$ & -0.211 & 0.08 & -0.328 & -2.648 & 0.010 & & & \\
\hline \multirow[t]{4}{*}{2} & (Constant) & 32.481 & 4.421 & & 7.347 & 0.000 & 0.209 & 5.031 & 0.004 \\
\hline & $\begin{array}{l}\text { Short-term } \\
\text { memory }\end{array}$ & -0.351 & 0.117 & -0.440 & -2.996 & 0.004 & & & \\
\hline & $\begin{array}{l}\text { Logical } \\
\text { thinking }\end{array}$ & -0.057 & 0.085 & -0.094 & -0.67 & 0.505 & & & \\
\hline & $\begin{array}{l}\text { Attentional } \\
\text { control }\end{array}$ & 0.062 & 0.089 & 0.095 & 0.696 & 0.489 & & & \\
\hline
\end{tabular}

Note: Dependent variable: Total score of the Beck depression

The HJ-Biplot allows a detailed examination of the variables for the neuropsychological and depression evaluation of women victims of abuse through a multivariate graphic representation.

The percentage of inertia explained by the first three axes is $89.6 \%$, with the first axis being the one with the greatest explained variability $(59.51 \%)$, the second explaining $18.14 \%$, and the third $11.95 \%$.

Table 5 shows that neuropsychological variables contribute substantially to the factorial axis 1, but low to axes 2 and 3. The total score of the Luria-DNA battery and short-term memory contribute fundamentally to factor axis 1 , while logical thinking and attentional control, in addition to contributing to this axis, also does substantially to axis 3 . The depression variable contributes mainly to axis 2 , a low contribution to axis 1 , and a negligible contribution to axis 3 .

Table 5. Relative contribution of factor to element

\begin{tabular}{lccc}
\hline & Axis 1 & Axis 2 & Axis 3 \\
\hline Short-term memory & 975.6 & 21.14 & 3.26 \\
Logical thinking & 634.14 & 9.6 & 356.26 \\
Attentional control & 540.07 & 207.02 & 252.91 \\
Total score Luria-DNA & 976.93 & 21.77 & 1.3 \\
Beck depression & 258.92 & 707.69 & 33.39 \\
\hline
\end{tabular}

Figure 2 shows the graphic representation of the HJ-Biplot in the 1-2 plane, where it clearly shows the direct relationship between the memory and attentional control variables with the total score of the Luria-DNA battery, as the angles formed by the 
vectors of these variables are acute. The high correlation between logical thinking and the total score of the Luria-DNA battery is also noteworthy (forming an angle whose opening is close to 0 degrees). On the other hand, an inverse relationship between short-term memory and depression is shown, forming an angle close to 180 degrees. The independence of attention control and depression in women victims of gender-based violence is also shown.

All the variables have noticeable variability due to the length of the vectors, where the vector corresponding to depression being the longest, while the one corresponding to logical thinking the shortest.

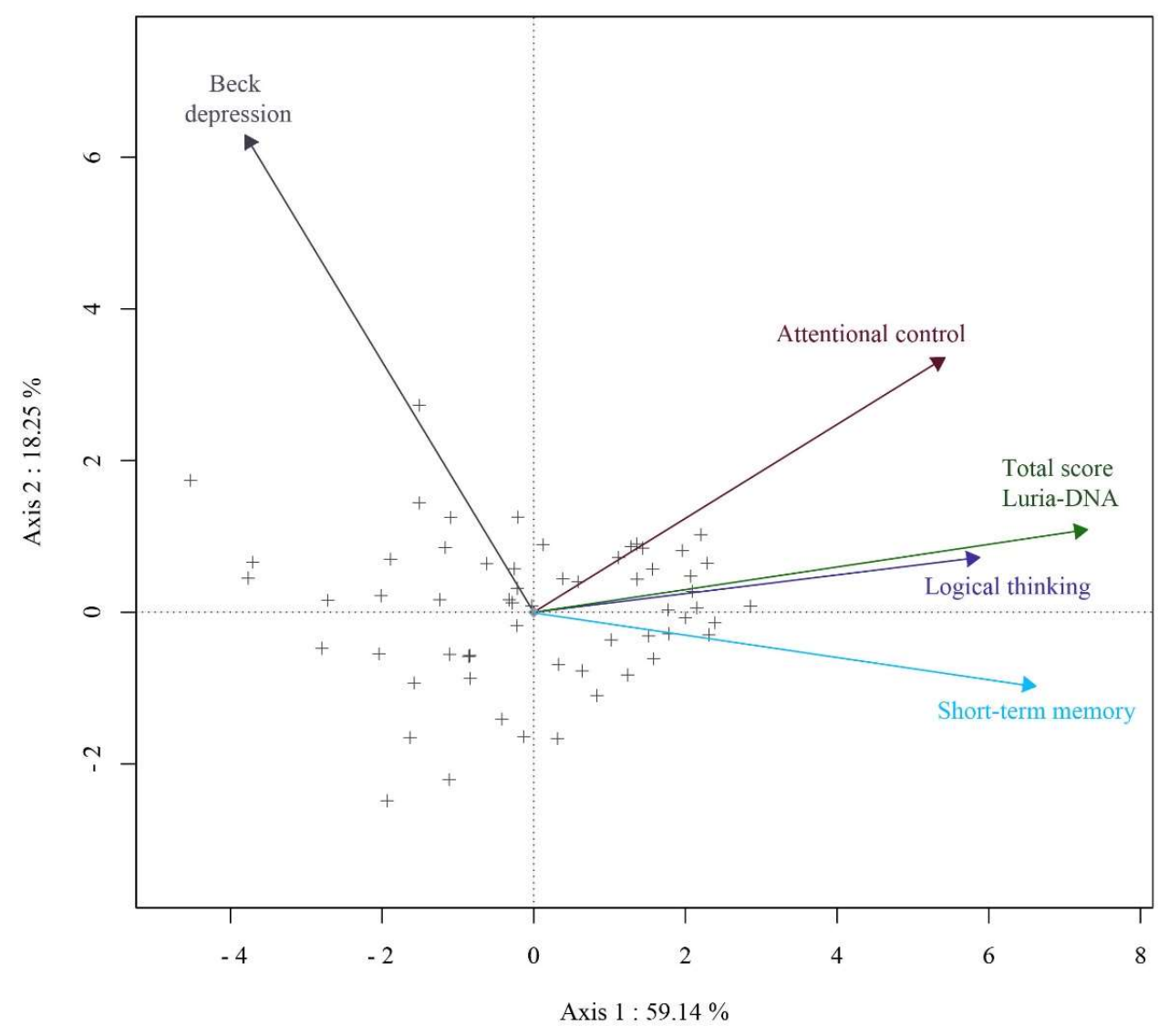

Figure2. 2D graph of HJ-Biplot factorial axis 1-2

Taking into account that women located in similar positions in the graph present a similar behavior, and that the plot of each woman with respect to a variable reflects the response of a woman on said variable, there are women who have suffered gender-based violence with high scores in the neuropsychological evaluation variables, and low in depression, or vice versa.

We distinguish three groups of women victims of gender-based violence (Figure 3):

Cluster 1 consists of $33.3 \%$ of women in the analyzed sample who have high scores in short-term memory $(M=56.00, S D=8.522)$, logical thinking $(M=54.25, S D=9.770)$, 
attentional control $(\mathrm{M}=55.25, \mathrm{SD}=5.955)$, and the total score of the Luria-DNA battery $(\mathrm{M}=59.75, \mathrm{SD}=7.340)$; and low scores in depression $(\mathrm{M}=15.30, \mathrm{SD}=6.300)$.

Cluster 2 consists of $10.0 \%$ of women in the sample who have very low scores in shortterm memory $(M=20.00, S D=20.488)$, logical thinking $(M=13.33, S D=10.801)$, attentional control $(\mathrm{M}=9.17, \mathrm{SD}=11.143)$, and total score of the Luria-DNA battery $(\mathrm{M}$ $=10.83, \mathrm{SD}=9.704)$; and high scores in depression $(\mathrm{M}=35.50, \mathrm{SD}=12.176)$.

Cluster 3 consists of $56.7 \%$ of women in the sample who have low scores in shortterm memory $(M=37.06, S D=10.525)$, logical thinking $(M=33.24, S D=17.315)$, attentional control $(\mathrm{M}=38.68, \mathrm{SD}=15.874)$, and total score of the Luria-DNA battery $(\mathrm{M}=31.03, \mathrm{SD}=9.830)$; and low scores in depression $(\mathrm{M}=16.68, \mathrm{SD}=12.030)$.

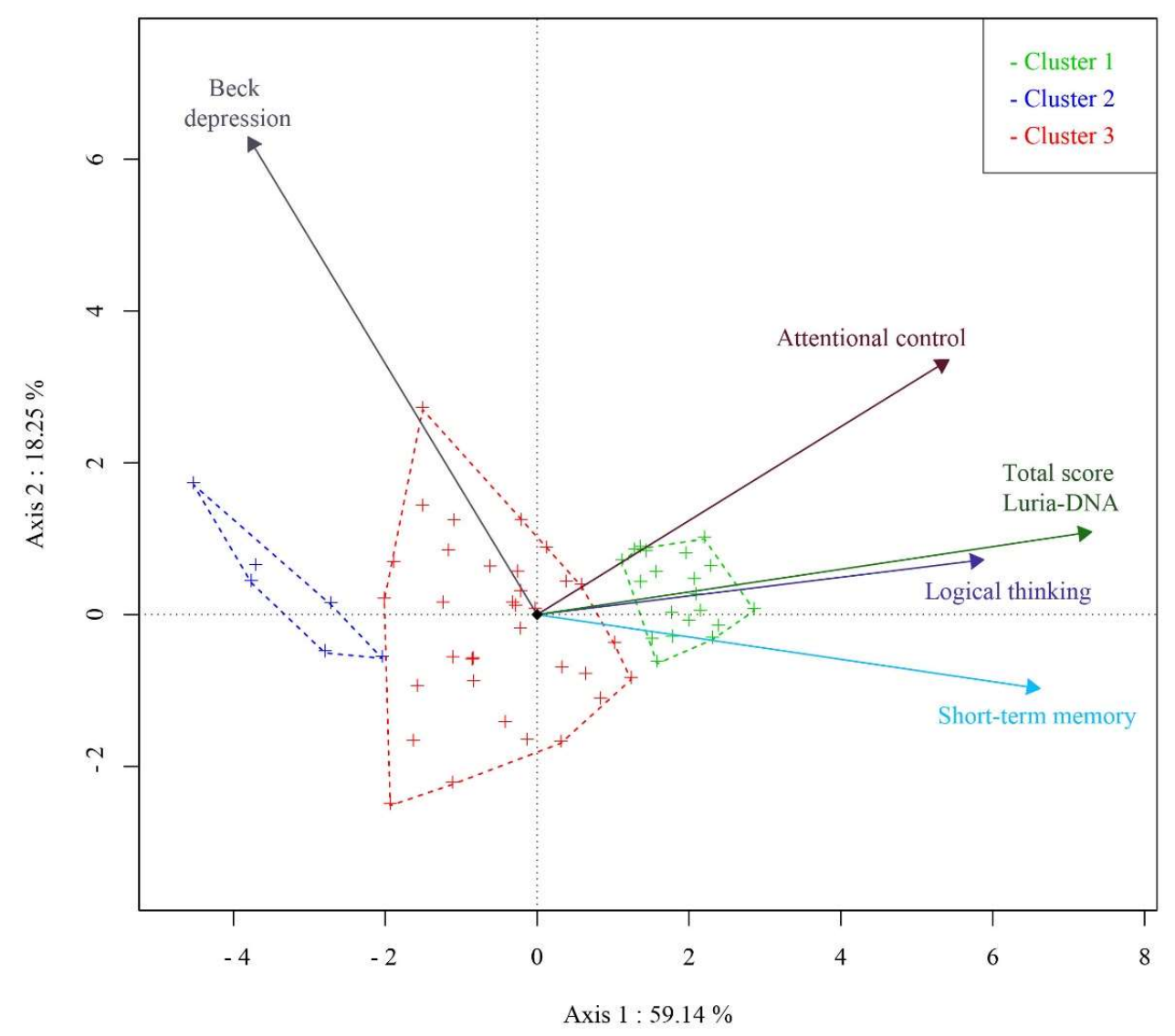

Figure3. 2D graph of HJ-Biplot factorial axis 1-2 by Clusters

\section{Discussion}

The results of this study show that women victims of gender-based violence suffer neuropsychological sequelae. Although the Luria-DNA battery indicates in these women a high average score in short-term memory and attentional control, it is also true that low scores are observed in logical thinking. However, when classifying them by levels according to the amplitude of responses of the Luria-DNA battery, most of the women in our sample have low short-term memory, low attentional control and a low total score of the Luria-DNA battery. 
On the other hand, we found that $59.02 \%$ of women who have suffered gender-based violence were classified as having some relevant type of depression. Additionally, we found significant differences in depression between the groups of women victims of gender-based violence, which are related to the level of short-term memory and the total score of the Luria-DNA battery.

Regarding the relationship that could exist between the neuropsychological evaluation and depression in women victims of gender-based violence, the total score of the neuropsychological evaluation can explain $10.8 \%$ of the variance of depression in women abuse victims. However, results of the neuropsychological variables Short-term memory, Logical thinking and Attentional control show an increase in the explanatory power of depression. It was observed that women who have suffered gender-based violence and who have high scores in short-term memory show lower depression values. Through the HJ-Biplot we found a direct relationship between the memory and attentional control variables with the total score of the Luria battery, highlighting the high correlation between logical thinking and the total score of the battery. On the other hand, there is an inverse relationship between short-term memory and depression.

In relation to these findings, three well-differentiated clusters of women victims of gender-based violence were identified:

- The first cluster is composed of women who have high scores in short-term memory, logical thinking, and total score of the Luria-DNA battery; and low scores in depression.

- The second cluster comprises women who have very low scores in short-term, logical thinking, attentional control, and total score of the Luria-DNA battery; and high scores in depression.

- And the third cluster consists of women in the sample who have low scores in shortterm, logical thinking, attentional control, and total score of the Luria-DNA battery; and low scores in depression.

In addition, when taking into account the duration of abuse suffered, we found in victims of gende-based violence that when it lasts less than 3 years, $66.67 \%$ of them showed depression. When endured for more than 10 years, $70 \%$ of them show some degree of depression. However, when endured between 4 and 10 years, the percentage drops to $42.67 \%$.

In this sense, it is noticeable to find in our sample that, out of the women with low depression, $58.33 \%$ suffered abuse between 4 and 10 years, $25.00 \%$ for more than 10 years, and $16.67 \%$ for less than 3 years. Among women with mild depression, $50.00 \%$ suffered abuse between 4 and 10 years, while in those with moderate or severe depression, the majority suffered abuse for more than 10 years ( $44.44 \%$ and $66.67 \%$ respectively). 


\section{References}

Billoux, S., Arbus, C., Telmon, N., \& Voltzenlogel, V. (2016). Autobiographical memory impairment in female victims of intimate partner violence. Journal of family violence, 31(7), 897-902.

Boira, S., Carbajosa, P., \& Méndez, R. (2015). Miedo, conformidad y silencio. La violencia en las relaciones de pareja en áreas rurales de Ecuador. PsychosocialIntervention. En Prensa. doi:10.1016/j.psi.2015.07.008.

Boira, S., Carbajosa, P., \& Méndez, R. (2016). Miedo, conformidad y silencio: la violencia en las relaciones de pareja en áreas rurales de Ecuador. Psychosocial Intervention, 25(1), 9-17.

Browne, A. (1993). Violence against women by male partners: Prevalence, outcomes, and policy implications. American psychologist, 48(10), 1077.

Bunnell, S. L., \&Greenhoot, A. F. (2012). When and why does abuse predict reduced autobiographical memory specificity? Memory, 20(2), 121-137. https://doi.org/10.1080/09658211.2011.648197.

Campbell, J. C. (2002). Health consequences of intimate partner violence. The lancet, 359(9314), 1331-1336.

Delara, M (2016). Mental health consequences and risk factors of physical intimate partner violence. Mental Health in Family Medicine, 12 (2016), pp. 119-125

Ellsberg, M., Jansen, H. A., Heise, L., Watts, C. H., \& Garcia-Moreno, C. (2008). Intimate partner violence and women's physical and mental health in the WHO multicountry study on women's health and domestic violence: an observational study. The lancet, 371(9619), 1165-1172.

Fonzo, G. A., Simmons, A. N., Thorp, S. R., Norman, S. B., Paulus, M. P., \& Stein, M. B. (2010). Exaggerated and disconnected insular-amygdalar blood oxygenation leveldependent response to threat-related emotional faces in women with intimate-partner violence posttraumatic stress disorder. Biological psychiatry, 68(5), 433-441. https://doi.org/10.1016/j.biopsych.2010.04.028

Galindo, M. P. (1986). An alternative for simultaneous representation: HJ-Biplot. Questiio, 10, 12-23.

Glasier, A., Gülmezoglu, A. M., Schmid, G. P., Moreno, C. G., \& Van Look, P. F. (2006). Sexual and reproductive health: a matter of life and death. TheLancet, 368(9547), 1595-1607.

Hidalgo-Ruzzante, N., Gómez, P., Bueso-Izquierdo, N., Jiménez, P., Martín Del Moral, E., \& Pérez-García, M. (2012). Secuelas cognitivas en mujeres víctimas de violencia de género. In Congreso para el estudio de la violencia contra las mujeres. 
IBM Corp. (2019). IBM SPSS Statistics for Windows, Version 26.0. Armonk, NY: IBM Corp [Software de ordenador] https://www.ibm.com/es-es/products/spssstatistics

Jackson, H., Philp, E., Nuttall, R. L., \& Diller, L. (2002). Traumatic brain injury: A hidden consequence for battered women. Professional Psychology: Research and Practice, 33(1), 39-45 doi: 10.1037/0735-7028.33.1.39

Jaen Cortés, C. I., Rivera Aragón, S., Amorín de Castro, E. F., \& Rivera Rivera, L. (2015). Violencia de pareja en mujeres: prevalencia y factores asociados. Acta de investigación Psicológica, 5(3), 2224- 2239. doi: 10.1016/S2007-4719(16)30012-6

Kwako, L. E., Glass, N., Campbell, J., Melvin, K. C., Barr, T., \& Gill, J. M. (2011). Traumatic brain injury in intimate partner violence: A critical review of outcomes and mechanisms. Trauma, Violence, \& Abuse, 12(3), 115-126. https://doi.org/10.1177/1524838011404251

Lozano-Ruiz, Fernández-Fillol, Daugherty, Amaoui, Gónzalez-Gónzalez, GarcíaMuñoz, Hidalgo-Ruzzante, Ibanez-Casas y Pérez-García (2019) Secuelas neuropsicológicas en atención en mujeres víctimas de violencia de género a partir de la tarea de cancelación de la batería EMBRACED. doi:10.13140/RG.2.2.24379.67369

Marín Torices, M. I., Hidalgo-Ruzzante, N., Daugherty, J. C., Jiménez-González, P., \& Pérez García, M. (2018). Validation of neuropsychological consequences in victims of intimate partner violence in a Spanish population using specific effort tests. The Journal of Forensic Psychiatry \& Psychology, 29(1), 86-98.

Marín Torices, M. I., Hidalgo-Ruzzante, N., Tovar Sabio, V., \& Pérez García, M. (2016). Neuropsicología forense en un caso de violencia de género. BehavioralPsychology/Psicologia Conductual, 24(2).

Navarro, C. G., León, F. G., \& Nieto, M. Á. P. (2020). Análisis de las consecuencias cognitivas y afectivas de la violencia de género en relación con el tipo de maltrato. Ansiedad y Estrés, 26(1), 39-45.

Oliver, M. S., de los Llanos, L. T., Vallejo, R. R., \& Hernández, A. I. (2014). Violencia de género y autoestima: efectividad de una intervención grupal. Apuntes de psicología, 32(1), 57-63

Mujeres, O. N. U. (2015). La igualdad de género. México Recuperado de: http://igualdaddegenero. unam. mx/wp-content/uploads/2016/08/onu-mujeres-igualdadequidad. pdf.

Nieto A.B., Galindo, P. \& Freitas, A. (2019). Package 'biplotbootGUI'. R package version 1.2: Bootstrap on Classical Biplots and Clustering Disjoint Biplot.

Seedat, S., Stein, M. B., \& Forde, D. R. (2005). Association between physical partner violence, posttraumatic stress, childhood trauma, and suicide attempts in a community sample of women. Violence and victims, 20(1), 87-98.

Simmons, A., Paulus, M. P., Thorp, S. R., Matthews, S. C., Norman, S. B., \& Stein, M. B. (2008). Functional activation and neural networks in women with posttraumatic stress disorder related to intimate partner violence. Biological psychiatry, 64(8), 681. https://doi.org/10.1016/j.biopsych.2008.05.027 
Stein, M. B., Kennedy, C. M., \&Twamley, E. W. (2002). Neuropsychological function in female victims of intimate partner violence with and without posttraumatic stress disorder. Biological psychiatry, 52(11), 1079-1088.

Sugg, N. (2015). Intimate Partner Violence: Prevalence, health consequences and intervention. Medical Clinicsfor North America, 99(3), 629-649. doi:10.1016/j.mcna.2015.01.012

Torres García, A. V. (2014). Evaluación neuropsicológica en mujeres víctimas de violencia de género. Tésis doctoral. Universidad de Salamanca, Salamanca, España.

Torres García, A. V. y Pérez Fernández, M. (2018). Evaluación neuropsicológica de las mujeres víctimas de la violencia de género, como herramienta en los procesos judiciales. I Congreso de políticas públicas. Universidad de Salamanca. ISBN 978-84-09-10221-1, págs. 477-490

Twamley, E. W., Allard, C. B., Thorp, S. R., Norman, S. B., Cissell, S. H., Berardi, K. H., ... Stein, M. B. (2009). Cognitive impairment and functioning in PTSD related to intimate partner violence. Journal of the International Neuropsychological Society, 15(6), 879-887. https://doi.org/10.1017/S135561770999049X

Twamley, E. W., Allard, C. B., Thorp, S. R., Norman, S. B., Hami Cissell, S. H., Berardi, K. H., Grimes, E. M. y Stein, M. B. (2009). Cognitive impairment and functioning in PTSD related to intimate partner violence. Journal of the International Neuropsychological Society, 15, 879-887.

Valera, E. M., \&Berenbaum, H. (2003). Brain injury in battered women. Journal of consulting and clinical psychology, 71(4), 797. http://dx.doi.org/10.1037/0022006X.71.4.797

Valera, E., \& Kucyi, A. (2017). Brain injury in women experiencing intimate partnerviolence: neural mechanistic evidence of an "invisible" trauma. Brainimaging and behavior, 11(6), 1664-1677. 